Article

\title{
Modeling of High-Efficiency Multi-Junction Polymer and Hybrid Solar Cells to Absorb Infrared Light
}

\author{
Jobeda J. Khanam and Simon Y. Foo * \\ Department of Electrical and Computer Engineering, FAMU-FSU College of Engineering, \\ Tallahassee, FL 32310, USA; jk16c@my.fsu.edu \\ * Correspondence: foo@eng.famu.fsu.edu; Tel.: +1-850-410-6474
}

Received: 7 January 2019; Accepted: 16 February 2019; Published: 22 February 2019

\begin{abstract}
In this paper, we present our work on high-efficiency multi-junction polymer and hybrid solar cells. The transfer matrix method is used for optical modeling of an organic solar cell, which was inspired by the McGehee Group in Stanford University. The software simulation calculates the optimal thicknesses of the active layers to provide the best short circuit current (JSC) value. First, we show three designs of multi-junction polymer solar cells, which can absorb sunlight beyond the $1000 \mathrm{~nm}$ wavelengths. Then we present a novel high-efficiency hybrid (organic and inorganic) solar cell, which can absorb the sunlight with a wavelength beyond $2500 \mathrm{~nm}$. Approximately $12 \%$ efficiency was obtained for the multi-junction polymer solar cell and $20 \%$ efficiency was obtained from every two-, three- and four-junction hybrid solar cell under 1 sun AM1.5 illumination.
\end{abstract}

Keywords: short circuit current density $\left(\mathrm{J}_{\mathrm{sc}}\right)$; open circuit voltage $\left(\mathrm{V}_{\mathrm{oc}}\right)$; power conversion efficiency (PCE); fill factor (FF); organic/ polymer solar cell (OSC); hybrid solar cell (HSC)

\section{Introduction}

In the past few years, polymer solar cells (PSCs) have been attracting much attention due to their ease of processing, low cost, flexibility and lightweight nature compared to the traditional inorganic solar cells. The thickness of the materials used in polymer solar cells is limited due to their high absorption coefficient [1-3]. Although the organic solar cell (OSC) has a good future, its efficiency is still very low compared to the silicon solar cell [4]. There have been various methods implemented, such as annealing, device structure tuning and active material modification, to improve the efficiency of the PSC [5]. Among the various methods involving two or more organic junctions, the tandem structure is one of the most effective solutions. Furthermore, the photovoltaic devices using a mixture of inorganic nanoparticles and conjugated polymers, called hybrid solar cells, have gained popularity due to their ability to absorb near-infrared light. To optimize the device performance, it is essential to adjust the thickness of active layers used in tandem photovoltaic cells. The optimization of a tandem structure using trial and error experiments is costly and sometimes ineffective. Simulation is a more effective tool to create the best tandem device structure. The OSC device is mainly made of an organic layer sandwiched between two different metal electrodes. A bulk heterojunction (BHJ) organic solar cell consists of three components: An active layer, band alignment layer and electrodes. The active layer is a homogeneous mixture of donor and acceptor materials. The donor materials are generally conjugated polymers, whereas the acceptor materials are fullerene derivatives. The power conversion efficiency of the most promising structure, which is namely the P3HT:PCBM bulk heterojunction solar cell, has been reported to be $5 \%$ [6,7]. Benaissa et al. [8] showed that the hybrid solar cell absorbs light until $800 \mathrm{~nm}$. The study by Islam [9] showed that the one-junction polymer solar cell with a P3HT:PCBM active layer can cover the $800 \mathrm{~nm}$ light spectrum with $2.9 \%$ efficiency. The study by Swapna et al. [10] showed that the one-junction polymer solar cell with MEHPPV:PCBM active 
layer covered the $800 \mathrm{~nm}$ light wavelength and only produced a current density of $6.82 \mathrm{~mA} / \mathrm{cm}^{2}$. Wei et al. [11] showed the tandem (two-junction) PSC, with the PCPDTBT:PCBM and P3HT:PCBM active layers providing 9\% efficiency. In most papers, the simulation and optimization were conducted for the one-junction PSC cells. In our paper, we showed that the multi-junction hybrid solar cell can absorb light beyond $2500 \mathrm{~nm}$ and cover the whole solar spectrum with $20 \%$ efficiency. We also created a tandem polymer with $12 \%$ efficiency. The device structure was arranged in such a way that the high band gap material on the top of the device and lower band gap materials on the bottom of the device were able to absorb the near-infrared spectrum of light. The tandem solar cell voltage was increased due to the multiple junctions and the current also increased as it covered the near-infrared spectrum, hence increasing efficiency.

\section{Materials and Methods}

\subsection{Theoretical Considerations}

The organic and inorganic materials used in this simulation are shown in Table 1 . To reduce the charge recombination, two different materials called the electron transport layer (ETL) and hole transport layer (HTL) are used, which collect the electron and hole, respectively, after charge separation in the interface [12].

Table 1. Description of organic and inorganic materials used in the simulation [13].

\begin{tabular}{|c|c|}
\hline Symbol & Name; Description \\
\hline $\mathrm{SiO}_{2}$ & Silicon dioxide, glass \\
\hline ITO & Indium tin oxide; electrode that collects hole/anode \\
\hline PEDOT: PSS & Poly polystyrene sulfonate; HTL \\
\hline P3HT & Poly(3-hexylthiophene-2,5-diyl), electron donor \\
\hline ICBA & Indene-C60 bisadduct, electron acceptor \\
\hline $\mathrm{TiO}_{2}$ & Titanium (IV) oxide, ETL \\
\hline PTB7-Th & $\begin{array}{l}\operatorname{Poly}\left(\left[2,6^{\prime}-4,8-d i(5-e t h y l h e x y l t h i e n y l) \text { benzo[1,2-b;3,3-b] dithiophene] }\right.\right. \\
\text { \{3-fluoro-2[(2-ethylhexyl) carbonyl] thieno[3,4-b] thiophenediyl\}), electron donor }\end{array}$ \\
\hline PCBM & [6,6]-phenyl-C71-butyric acid methyl ester, electron acceptor \\
\hline PDTP-DFBT & $\begin{array}{l}\text { Poly[2,7-(5,5-bis-(3,7-dimethyloctyl)-5H-dithieno[3,2-b:2' }{ }^{\prime} 3^{\prime} \text {-d] } \\
\text { pyran)-alt-4,7-(5,6-difluoro-2,1,3-benzothia diazole); electron donor }\end{array}$ \\
\hline $\mathrm{Al}$ & Aluminum; electrode that collects electron/cathode \\
\hline PMDPP3T & 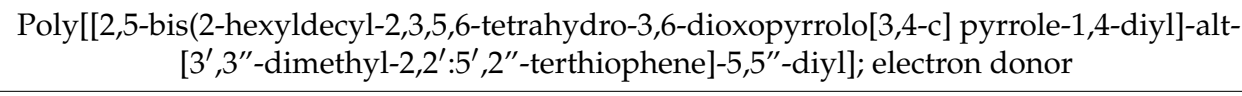 \\
\hline Si-PCPDTBT & $\begin{array}{l}\text { Poly[2,1,3-benzothiadiazole-4,7-diyl[4,4-bis(2-ethylhexyl)-4H-silolo [3,2-b:4,5-b'] } \\
\text { dithiophene-2,6-diyl]]; electron donor }\end{array}$ \\
\hline $\mathrm{MaPbI}_{3}$ & Methylammonium lead iodide; semiconducting organic-inorganic material \\
\hline $\mathrm{PbS}$ & Lead (II) sulphide; semiconducting inorganic material \\
\hline $\mathrm{ZnO}$ & Zinc oxide; ETL \\
\hline $\mathrm{Ag}$ & Silver; electrode that collects electron/cathode \\
\hline $\mathrm{NiO}$ & Nickel (II) oxide; HTL \\
\hline
\end{tabular}

\subsection{Solar Cell Modeling}

The optical transfer matrix theory describes the optical processes inside a thin film layer stack, which is used to evaluate the power conversion efficiency of the multi-junction photovoltaic cell [14]. The theory is explained by Roman et al. in detail [15]. When the light that has the energy of a photon 
with angular frequency $\omega$ strikes the organic solar cell, local energy dissipation takes place. The local energy dissipated in the organic solar cell at the point $\mathrm{z}$ is given by:

$$
\mathrm{Q}(\mathrm{z})=\frac{1}{2} \mathrm{c} \varepsilon_{0} \alpha \mathrm{n}|\mathrm{E}(\mathrm{z})|^{2}
$$

where $\varepsilon_{0}$ is the permittivity of the vacuum; $n$ is the real index of refraction; $\alpha\left(\alpha=\frac{4 \pi \mathrm{k}}{\lambda}\right)$ is the absorption coefficient; $\mathrm{k}$ is the extinction coefficient; $\mathrm{c}$ is the speed of light; $\lambda$ is the wavelength and $\mathrm{E}$ is the optical electric field at the point $z$.

$G(z, \lambda)$, the exciton generation rate as a function of depth and wavelength, is given by:

$$
\mathrm{G}(\mathrm{z}, \lambda)=\frac{\mathrm{Q}(\mathrm{z}, \lambda)}{\hbar \omega}
$$

where $\mathrm{h}$ is the plank constant and $\hbar=\frac{\mathrm{h}}{2 \pi}$.

Finally, one obtains the exciton generation rate at a depth of $z$ by summing $G(z, \lambda)$ over the visible spectrum:

$$
\mathrm{G}(\mathrm{z})=\sum_{\lambda=300}^{\lambda=2500} \mathrm{G}(\mathrm{z}, \lambda)
$$

For active layer thickness $=\mathrm{t}$ and assuming 100\% internal quantum efficiency, the current density $\left(\mathrm{mA} / \mathrm{cm}^{2}\right) \mathrm{J}_{\mathrm{sc}}$ under AM1.5 illumination is given by:

$$
\mathrm{J}_{\mathrm{sc}}=\mathrm{q} \times \int_{0}^{\mathrm{t}} \mathrm{G}(\mathrm{z}) \mathrm{dz}
$$

We get the J-V characteristics from the following equation:

$$
\mathrm{J}=\mathrm{J}_{\mathrm{sc}}-\mathrm{J}_{\mathrm{o}}\left(\exp \left(\frac{\mathrm{q}\left(\mathrm{V}+\mathrm{J} \cdot \mathrm{R}_{\mathrm{s}}\right)}{\mathrm{KT}}\right)-1\right)-\frac{\mathrm{V}+\mathrm{J} \cdot \mathrm{R}_{\mathrm{s}}}{\mathrm{R}_{\mathrm{sh}}}
$$

where $\mathrm{J}_{\mathrm{o}}=\mathrm{J}_{\mathrm{sc}} /\left(\exp \left(\frac{\mathrm{q} \cdot \mathrm{V}_{\mathrm{oc}}}{\mathrm{KT}}\right)-1\right) . \mathrm{J}_{\mathrm{o}}$ is the saturation current density $\left(\mathrm{mA} / \mathrm{cm}^{2}\right)$ under reverse bias; $\mathrm{V}_{\mathrm{oc}}$ is the open circuit voltage; $\mathrm{J}_{\mathrm{sc}}$ is the short circuit current density; $\mathrm{q}$ is the elementary charge; $\mathrm{k}$ is the Boltzmann constant; $\mathrm{T}$ is the temperature $(\mathrm{K} ;)$ and $\mathrm{V}$ is the output voltage. We consider a serial resistance $R_{s}=0.1 \Omega \mathrm{cm}^{2}$, related to contact and bulk semiconductor resistances and a shunt resistance $\mathrm{R}_{\mathrm{sh}}=1000 \Omega \mathrm{cm}^{2}$.

A very important parameter is the fill factor $(\mathrm{FF})$, which is defined as:

$$
\mathrm{FF}=\mathrm{P}_{\max } /\left(\mathrm{V}_{\mathrm{oc}} \cdot \mathrm{J}_{\mathrm{sc}}\right)=\left(\mathrm{V}_{\max } \cdot \mathrm{J}_{\max }\right) /\left(\mathrm{V}_{\mathrm{oc}} \cdot \mathrm{J}_{\mathrm{sc}}\right)
$$

The main parameter related to the cell performances is the power conversion efficiency (PCE) $\eta$ :

$$
\eta=\frac{\mathrm{V}_{\max } \cdot \mathrm{J}_{\max }}{\mathrm{P}_{\mathrm{in}}}=\mathrm{FF} \frac{\mathrm{V}_{\mathrm{oc}} \cdot \mathrm{J}_{\mathrm{sc}}}{\mathrm{P}_{\mathrm{in}}}
$$

where $\mathrm{J}_{\max }$ and $\mathrm{V}_{\max }$ are the current density and voltage that correspond to the maximum power $\mathrm{P}_{\max }$ delivered by the solar cell. $\mathrm{P}_{\text {in }}$ is the incident photon flux $\left(\right.$ in $\mathrm{mWcm}^{-2}$ ) that corresponds to AM 1.5 (i.e., $P_{\text {in }}$ is $100 \mathrm{mWcm}^{-2}$ ).

The organic absorber materials are composed of a semiconductor-like materials where the band gap corresponds to the difference between the Lowest Unoccupied Molecular Orbital (LUMO) and the Highest Occupied Molecular Orbital (HOMO). The $\mathrm{V}_{\mathrm{oc}}$ can be calculated by the following equation [16,17]:

$$
\operatorname{Voc}=\left[\frac{\operatorname{HOMO}(\mathrm{D})-\mathrm{LUMO}(\mathrm{A})}{\mathrm{q}}\right]-0.3 \mathrm{~V}
$$


where HOMO (D) is the highest molecular orbital of donor material and LUMO (A) is the lowest molecular orbital of acceptor materials.

The HOMO and LUMO levels of the donor and acceptor used in the paper are shown in Table 2. The $\mathrm{V}_{\text {oc }}$ for the inorganic materials PbS is 0.6V [18]. The MATLAB program has been obtained from the McGehee Group MATLAB software. The transfer matrix method is used to calculate the transmission, reflection and attenuation by using the MATLAB software. The theory for the calculation is described in detail in the literature $[19,20]$. The input data are the names of materials which build the structure of the cell and their corresponding thickness $(\mathrm{nm})$; as well as the real and imaginary parts of the complex refraction index of each material. From the Index_of_Refraction_library.xls file, the software will use the $\mathrm{n}$ and $\mathrm{k}$ refraction index for each selected material (See Supplementary Materials Figures S1-S8 for details) [21-23]. Under AM1.5 illumination (assuming 100\% internal quantum efficiency) at all wavelengths, the software calculates generation rate $(\mathrm{G})$ and $\mathrm{J}_{\mathrm{sc}}$ by using Equation (1) to Equation (4) using these input data. By using the input $\mathrm{n}$ and $\mathrm{k}$ refraction index data for all the materials used in a cell for a wavelength range, we can determine how much light was absorbed and reflected by the cell. The J-V characteristics are calculated by using Equation (5). The fill factor and power conversion efficiency are calculated by Equation (6) and Equation (7), respectively. We can calculate the $V_{o c}$ from Equation (8) by using the corresponding active layer HOMO and LUMO level. The AM 1.5 illumination used in the simulation [21], where we can see that the globe absorbs the solar irradiance $\left(\mathrm{mW} / \mathrm{cm}^{2}\right)$ up to a wavelength of $2500 \mathrm{~nm}$.

Table 2. The HOMO and LUMO level of donor and acceptor of materials used in the simulation [13].

\begin{tabular}{ccc}
\hline MATERIAL & LUMO $(\mathbf{e V})$ & HOMO $(\mathbf{e V})$ \\
\hline PTB7-Th(donor) & -3.61 & -5.25 \\
\hline PCBM (acceptor) & -3.9 & -5.9 \\
\hline PMDPP3T(donor) & -3.6 & -5.2 \\
\hline P3HT (donor) & -3.1 & -5 \\
\hline PCPDTBT (donor) & -3.55 & -5.3 \\
\hline MAPbI3 & -3.93 & -5.46 \\
\hline ICBA (acceptor) & -3.74 & -5.6 \\
\hline Si-PCPDTBT (donor) & -3.55 & -5.3 \\
\hline PDTP-DFBT (donor) & -3.64 & -5.26 \\
\hline
\end{tabular}

\section{Results}

\subsection{Results for Multi-Junction Polymer Solar Cells}

Three types of multi-junction polymer solar cells were investigated. Based on different active layers, we stacked the cell. The J-V characteristics and variation of light intensity on the cell were analyzed. The power conversion efficiency was calculated from the J-V curve. These three types of multi-junction polymer solar cell were simulated.

\subsubsection{Type 1: Multi-Junction Polymer Solar Cell}

By using the high, medium and low bandgap organic materials, we arranged the stack for solar cells. The number of active layers determined the number of junctions. For the first multi-junction polymer solar cell, we used three active layers and hence it is called the three-junction polymer solar cell. During the first step, we determined the optical properties of a cell whose dimensions are given by: Glass/ITO $(110 \mathrm{~nm}) /$ PEDOT:PSS (25 nm)/P3HT:ICBA $(190 \mathrm{~nm}) / \mathrm{TiO}_{2}(25 \mathrm{~nm}) /$ PEDOT:PSS $\left.(25 \mathrm{~nm}) / \mathrm{PTB} 7-\mathrm{Th}: \mathrm{PCBM} 270 \mathrm{~nm}\right) / \mathrm{TiO}_{2}(25 \mathrm{~nm}) /$ PEDOT:PSS $(25 \mathrm{~nm}) /$ PDTP-DFBT:PCBM $(640 \mathrm{~nm}) / \mathrm{TiO}_{2}(25 \mathrm{~nm}) / \mathrm{Al}(200 \mathrm{~nm})$. The thickness of the active layer 
affects the open circuit voltage $\left(\mathrm{V}_{\mathrm{oc}}\right)$ as well as the short circuit current $\left(\mathrm{J}_{\mathrm{sc}}\right)$ and thus the overall power conversion efficiency (PCE). To optimize various active layers, we use a general rule of thumb that decreasing the active layer thickness will increase the $V_{o c}$ due to shorter diffusion length, while increasing the thickness will increase the $\mathrm{J}_{\mathrm{sc}}$. Thus, we must optimize the cell to obtain the maximum performance. The active layer thickness was estimated by using the MATLAB code [21]. We can see in Figure 1 that the maximum total current that is possible from the type 1 solar cell is $30 \mathrm{~mA} / \mathrm{cm}^{2}$. As the three junctions are connected in series, each junction should provide $10 \mathrm{~mA} / \mathrm{cm}^{2}$ to obtain a maximum current of $30 \mathrm{~mA} / \mathrm{cm}^{2}$ from the cell. We can see from Figure 1 that if we set certain thicknesses (190 nm for P3HT:ICBA active layer, $270 \mathrm{~nm}$ for PTB7-Th:PCBM active layer and $640 \mathrm{~nm}$ for PDTP-DFBT:PCBM active layer), we can obtain $10 \mathrm{~mA} / \mathrm{cm}^{2}$ for each junction. Using the MATLAB code [21], we similarly calculated all the multi-junction polymer and hybrid cells optimized thickness. The HOMO and LUMO band diagram for the type 1 multi-junction PSC is shown in Figure 2. We can see from Figure 2 that with an active layer containing three different bandgaps, we determined that the open circuit voltage $\mathrm{V}_{\text {oc }}$ is $2.368 \mathrm{~V}$.

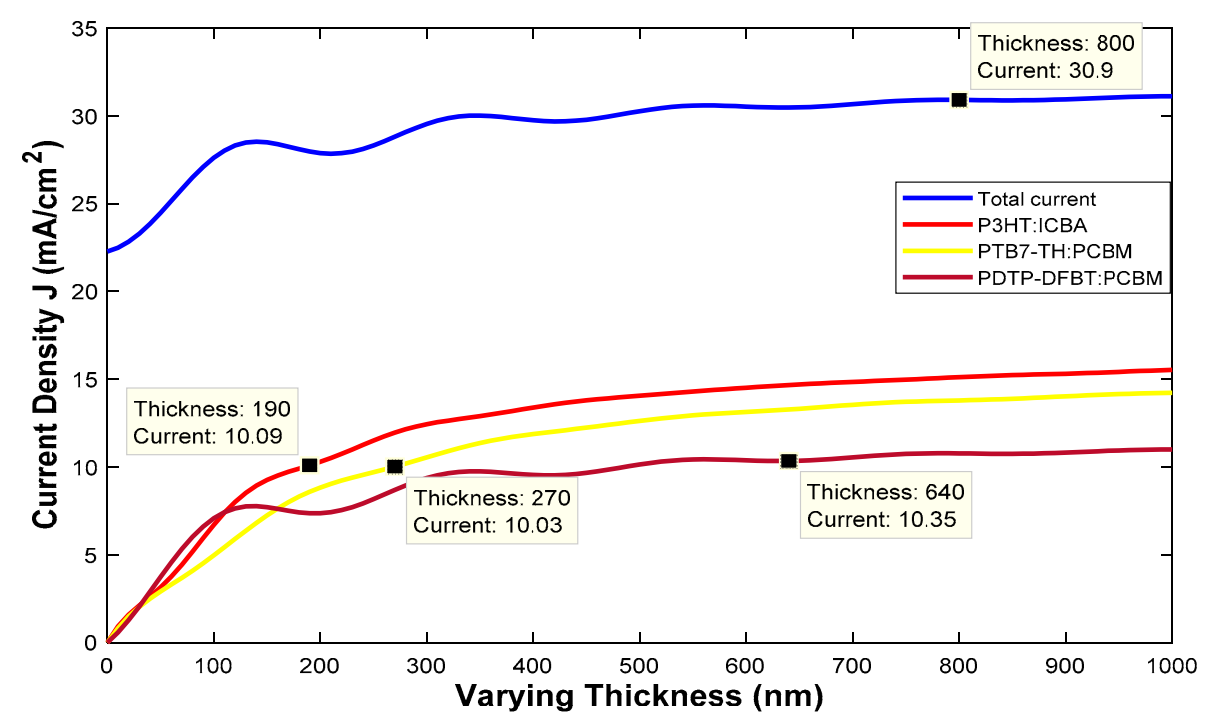

Figure 1. The thickness of the active layer is varied to obtain the optimal current for type 1 multi-junction polymer solar cells (PSC).
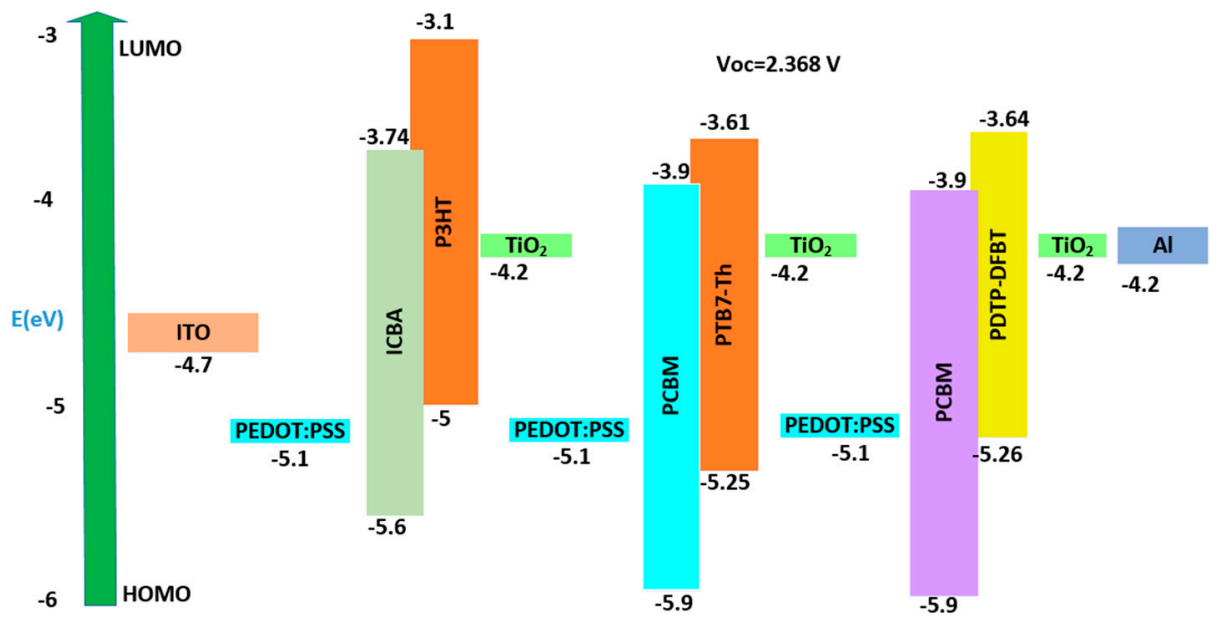

Figure 2. HOMO and LUMO band diagram for type 1 multi-junction PSC.

The stack diagram for the three-junction OSC is shown in Figure 3a. From Figure 3b, we can see that the three active layers of P3HT:ICBA (high bandgap), PTB7-Th:PCBM (medium bandgap) and PDTP-DFBT:PCBM (low bandgap) cover the solar spectrum with wavelengths of $300-1000 \mathrm{~nm}$ and the 
absorbed light intensity is above $70 \%$. From the simulation, we determined that $\mathrm{J}_{\mathrm{sc}}$ at each junction was $10.0194 \mathrm{~mA} / \mathrm{cm}^{2}$. The J-V characteristics are shown in Figure 3c. A PCE of $12.73 \%$ was achieved with this configuration.

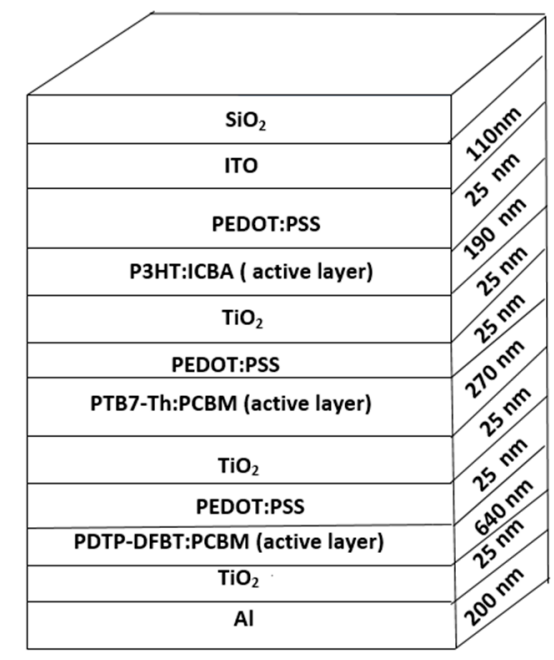

(a)

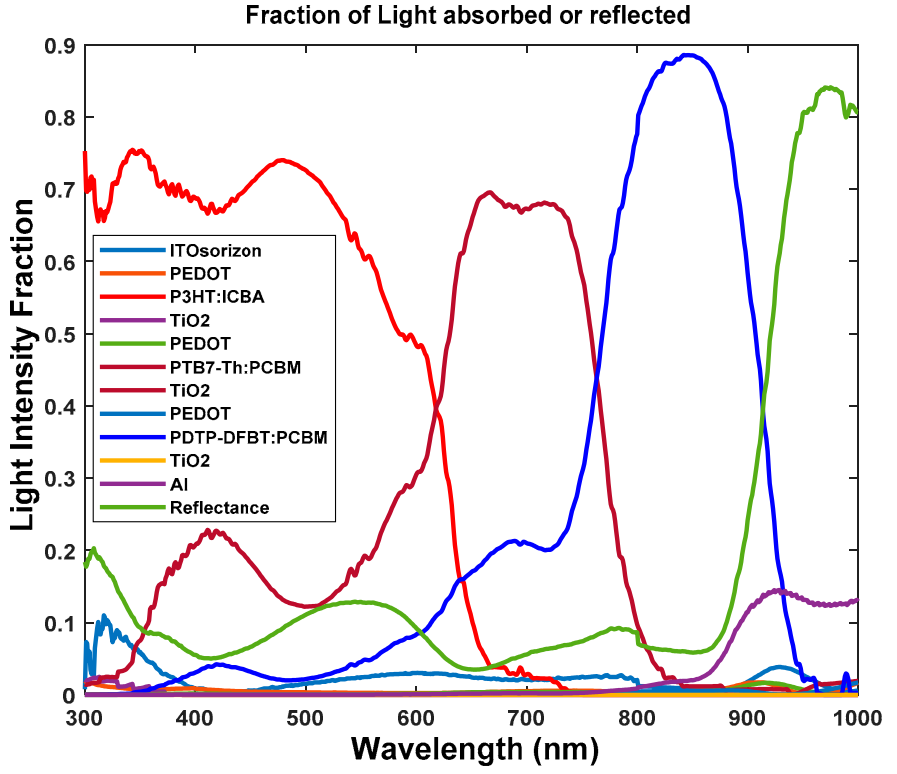

(b)

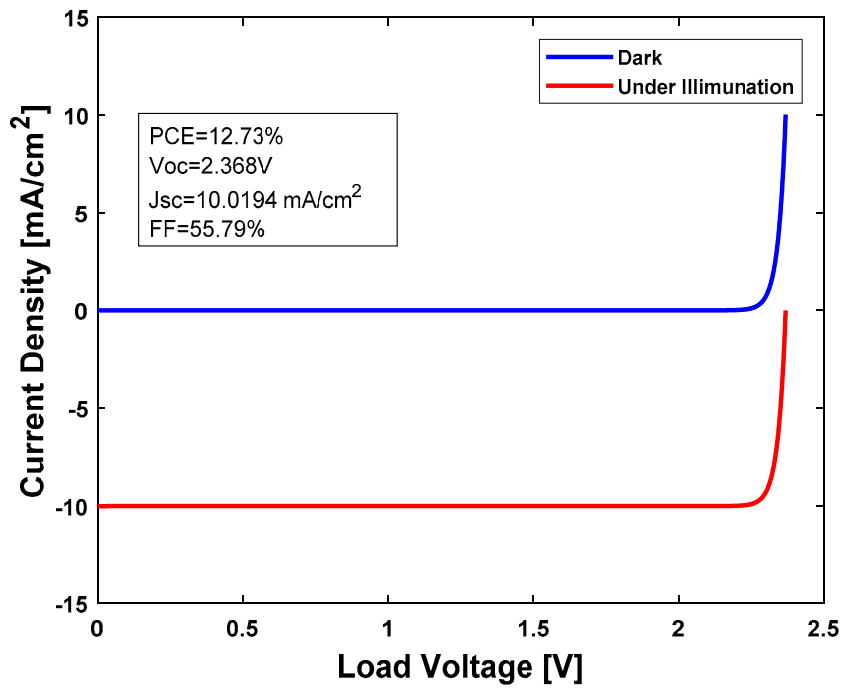

(c)

Figure 3. (a) Stack diagram; (b) variation of light intensity versus wavelength; and (c) J-V characteristics of three-junction organic solar cell (OSC) with front P3HT:ICBA, middle PTB7-Th:PCBM and rear PDTP-DFBT:PCBM active layers.

\subsubsection{Type 2: Multi-Junction Polymer Solar Cell}

The optical properties of the second three-junction OSC were investigated. The dimensions of the cell are described as follows: Glass/ITO (110 nm)/PEDOT:PSS (25 nm)/P3HT:ICBA $(235 \mathrm{~nm}) / \mathrm{TiO}_{2}(25 \mathrm{~nm}) /$ PEDOT:PSS $(25 \mathrm{~nm}) / \mathrm{Si}-\mathrm{PCPDTBT}: \mathrm{PCBM}(290 \mathrm{~nm}) / \mathrm{TiO}_{2}(25 \mathrm{~nm}) /$ PEDOT:PSS $(25 \mathrm{~nm}) / \mathrm{PMDPP} 3 \mathrm{~T}: \mathrm{PCBM}(1000 \mathrm{~nm}) / \mathrm{TiO}_{2}(25 \mathrm{~nm}) / \mathrm{Al}(200 \mathrm{~nm})$. The HOMO and LUMO band diagram for the type 2 multi-junction PSC is shown in Figure 4. We can see from Figure 4 that with an active layer of three different bandgaps, we determined that the open circuit voltage $\mathrm{V}_{\mathrm{oc}}$ is $2.07 \mathrm{~V}$. 


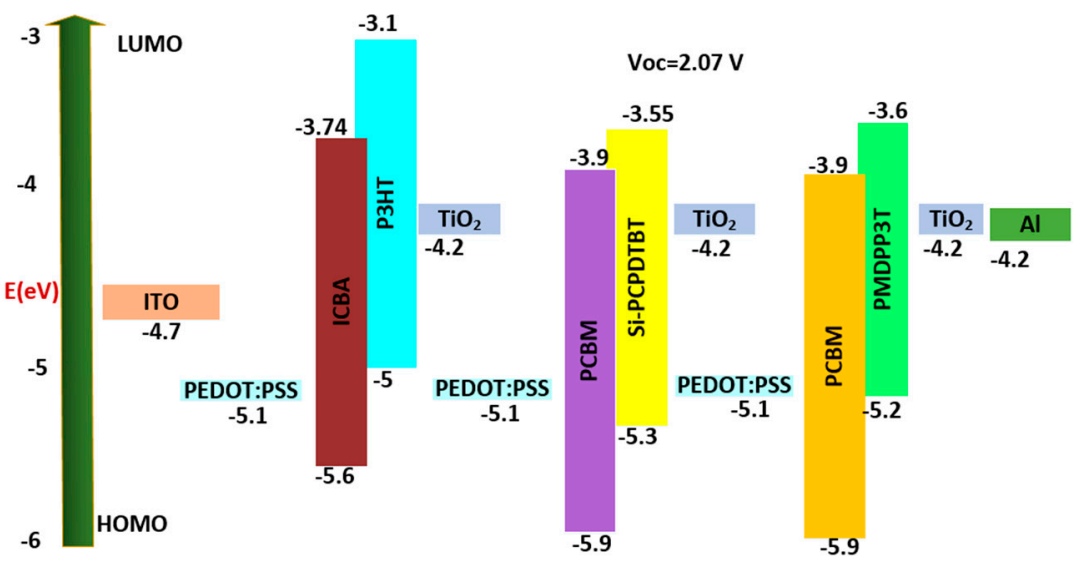

Figure 4. HOMO and LUMO band diagram for type 2 multi-junction PSC.

The stack diagram for the three-junction OSC is shown in Figure 5a. From Figure 5b, we can see that the three active layers of P3HT:ICBA, Si-PCPDTBT:PCBM and PMDPP3T:PCBM (low bandgap) cover the solar spectrum with wavelengths of $300-1000 \mathrm{~nm}$ and the light intensity is above $70 \%$. J-V characteristics are shown in Figure $5 \mathrm{c}$. From the simulation, we determined that $\mathrm{J}_{\mathrm{sc}}$ at each junction was $10.1962 \mathrm{~mA} / \mathrm{cm}^{2}$. A PCE of $10.03 \%$ was achieved with this configuration with FF of $47.52 \%$.

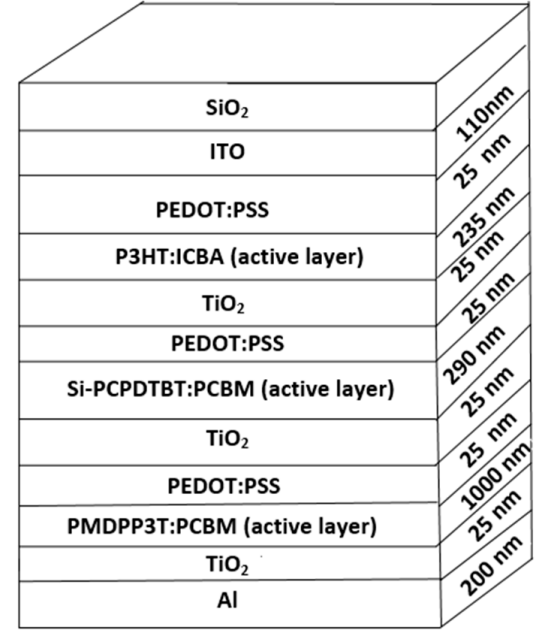

(a)

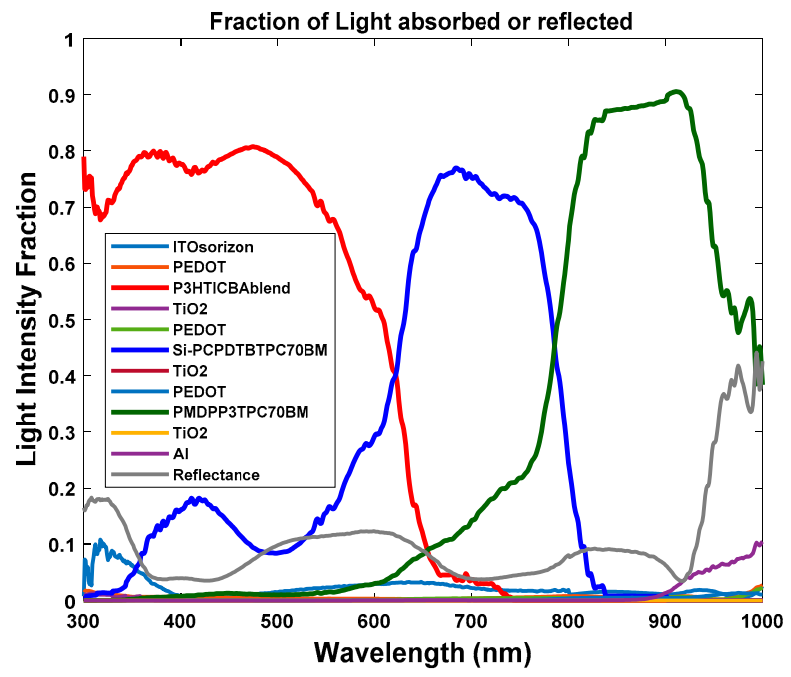

(b)

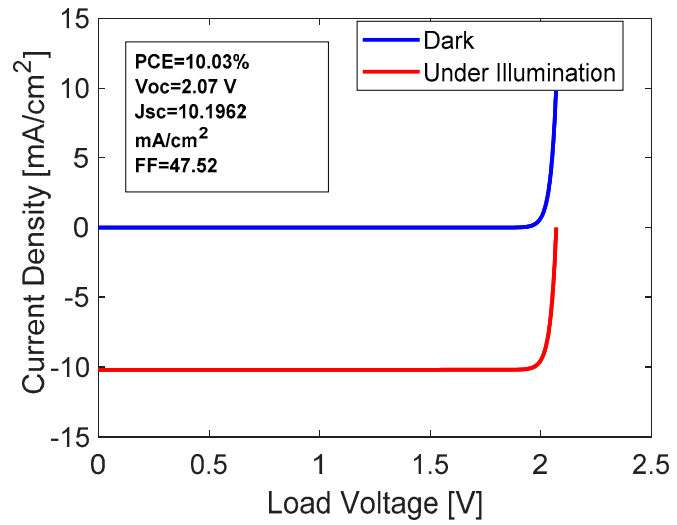

(c)

Figure 5. (a) Stack diagram; (b) variation of light intensity versus wavelength; and (c) J-V characteristics for OSC with P3HT:ICBA, Si-PCPDTBT:PCBM and PMDPP3T:PCBM active layers. 


\subsubsection{Type 3: Multi-Junction Polymer Solar Cell}

The third three-junction OSC was investigated. The dimensions of the cell were Glass/ITO (110 nm)/PEDOT:PSS $(25 \mathrm{~nm}) /$ P3HT: ICBA $(200 \mathrm{~nm}) / \mathrm{TiO}_{2}(25 \mathrm{~nm}) /$ PEDOT:PSS $(25 \mathrm{~nm}) / \mathrm{Si}$-PCPDTBT:PCBM $(290 \mathrm{~nm}) / \mathrm{TiO}_{2}(25 \mathrm{~nm}) /$ PEDOT:PSS $(25 \mathrm{~nm}) /$ PDTP-DFBT:PCBM $(1000 \mathrm{~nm}) / \mathrm{TiO}_{2}(25 \mathrm{~nm}) / \mathrm{Al}(200 \mathrm{~nm})$. The HOMO and LUMO band diagram for the type 1 multi-junction PSC is shown in Figure 6. We can see from Figure 6 that with an active layer of three different bandgaps, we determined that the open circuit voltage $\mathrm{V}_{\mathrm{oc}}$ is $2.17 \mathrm{~V}$.
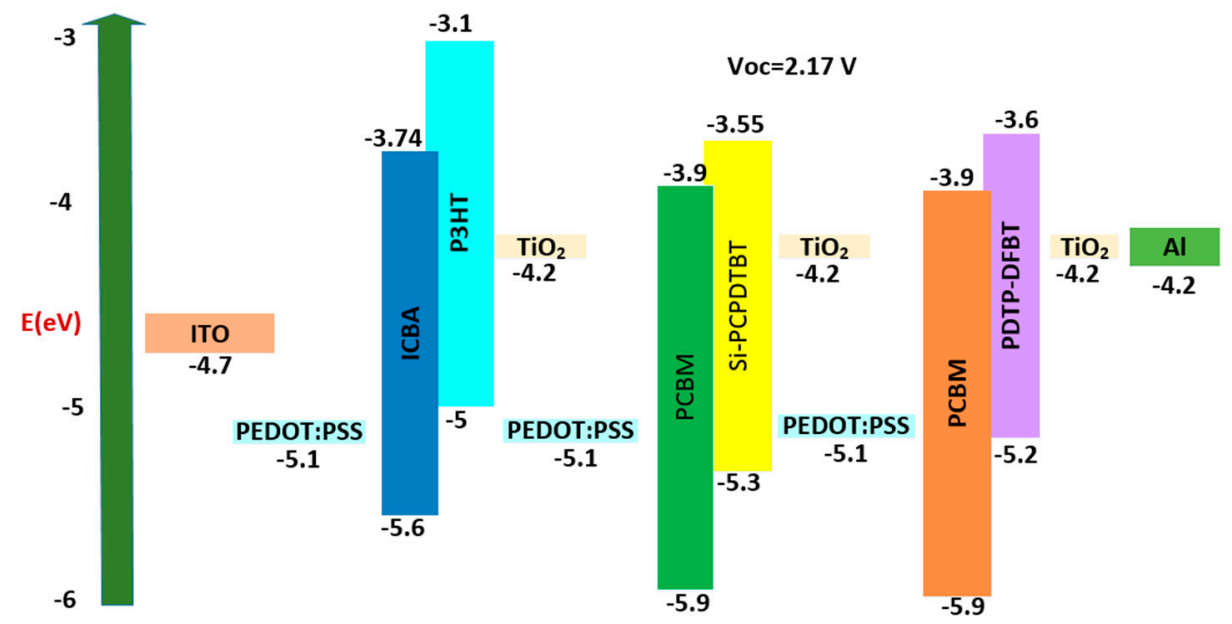

Figure 6. HOMO and LUMO band diagram for type 3 multi-junction PSC.

The stack diagram for the three-junction OSC is shown in Figure 7a. From Figure $7 \mathrm{~b}$, we can see that the three active layers of P3HT:ICBA, Si-PCPDTBT:PCBM and PDTP-DFBT:PCBM cover the solar spectrum with a wavelength in the range of $300-1000 \mathrm{~nm}$ and the light intensity is above $80 \%$. J-V characteristics are shown in Figure 7c. From the simulation, we determined that the $\mathrm{J}_{\mathrm{sc}}$ at each junction was $10.0130 \mathrm{~mA} / \mathrm{cm}^{2}$. A PCE of $10.90 \%$ was achieved using this configuration with FF of $50.17 \%$. 


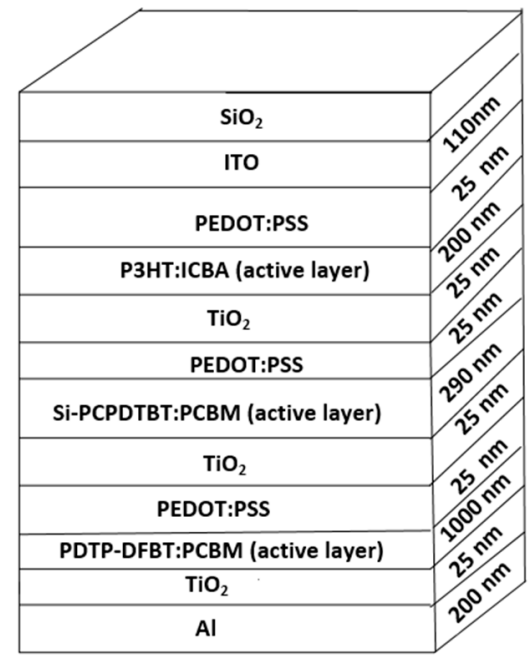

(a)

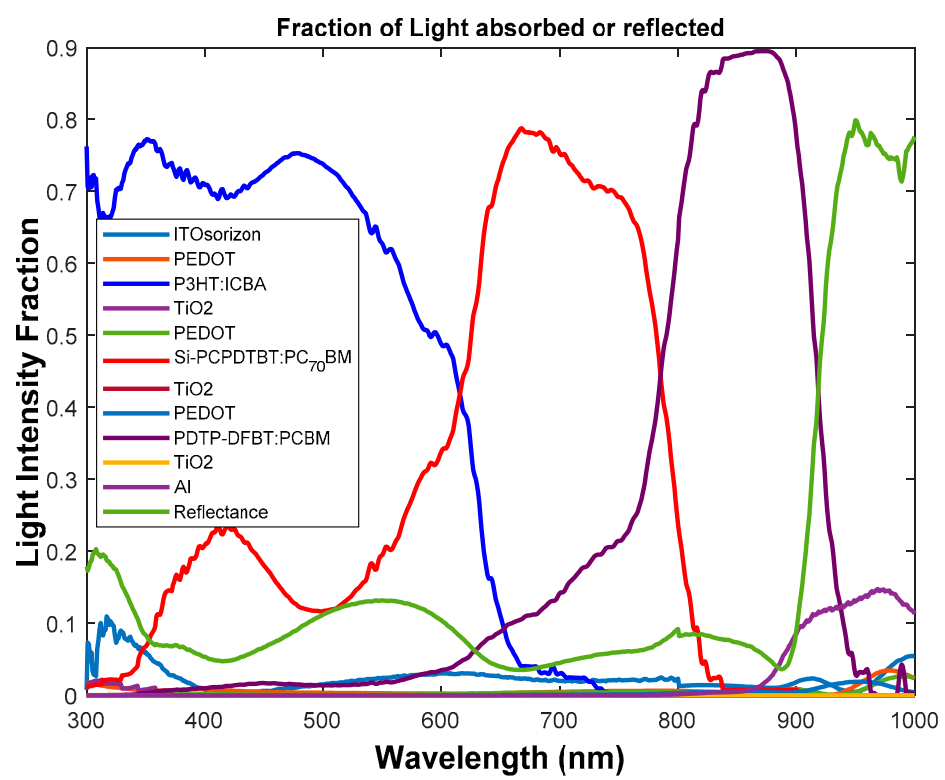

(b)

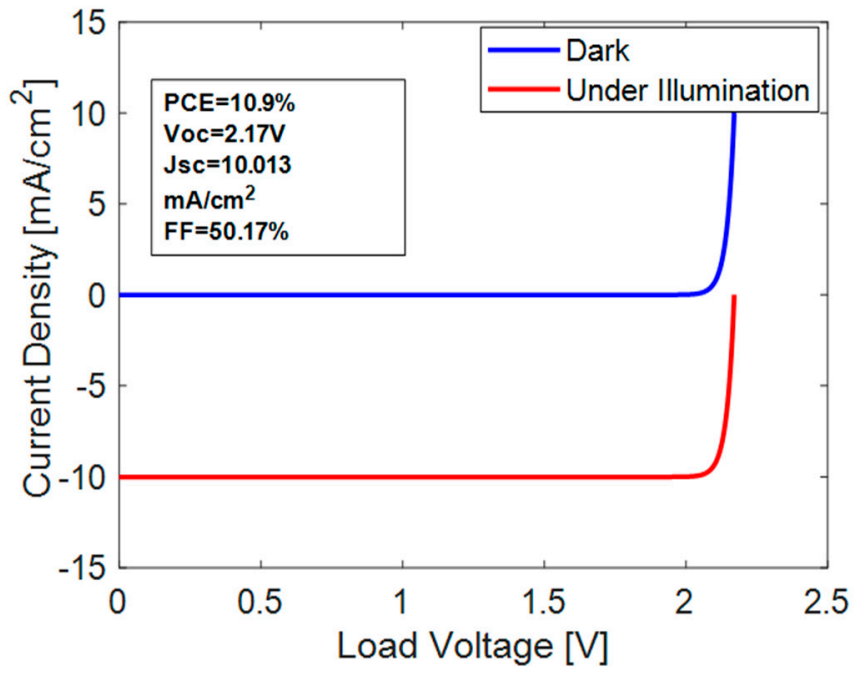

(c)

Figure 7. (a) Stack diagram; (b) variation of light intensity versus wavelength; and (c) J-V characteristics of OSC with P3HT:ICBA, Si-PCPDTBT:PCBM and PDTP-DFBT:PCBM active layers.

\subsection{Results for Two-, Three- and Four-Junction Hybrid Solar Cell}

Here, two-, three- and four-junction hybrid solar cells were investigated. Based on different active layers, we stacked the cell. The J-V characteristics and variation of light intensity on the cell were analyzed. The power conversion efficiency was calculated from the J-V curve.

\subsubsection{Two-Junction Hybrid Solar Cell}

First, the two-junction hybrid solar cell (HSC) was simulated. The lead sulfide (PbS) was used as a low bandgap material to absorb light beyond the infrared spectrum. The active layer $\mathrm{MaPbI}_{3}$ is organic and inorganic while $\mathrm{PbS}$ in HSC is inorganic in nature. During the first step, we determined the optical properties of a cell whose dimensions are given by: Glass/ITO $(100 \mathrm{~nm}) /$ PEDOT:PSS $(20 \mathrm{~nm}) /$ P3HT:ICBA $(300 \mathrm{~nm}) / \mathrm{TiO}_{2}(25 \mathrm{~nm}) /$ PEDOT:PSS $(20 \mathrm{~nm}) / \mathrm{MaPbI}_{3}$ $(1110 \mathrm{~nm}) / \mathrm{TiO}_{2}(25 \mathrm{~nm}) /$ PEDOT:PSS $(20 \mathrm{~nm}) / \mathrm{PbS}(3000 \mathrm{~nm}) / \mathrm{ZnO}(25 \mathrm{~nm}) / \mathrm{Ag}(200 \mathrm{~nm})$. The stack diagram for the three-junction OSC is shown in Figure 8a. From Figure 8b, we can see that the two 
active layers of $\mathrm{MaPbI}_{3}$ and rear $\mathrm{PbS}$ active layers cover the solar spectrum with wavelengths of $300-2500 \mathrm{~nm}$ and the light intensity is above $80 \%$. From Figure $8 \mathrm{c}$, we can see that only the active layers are creating excitons.

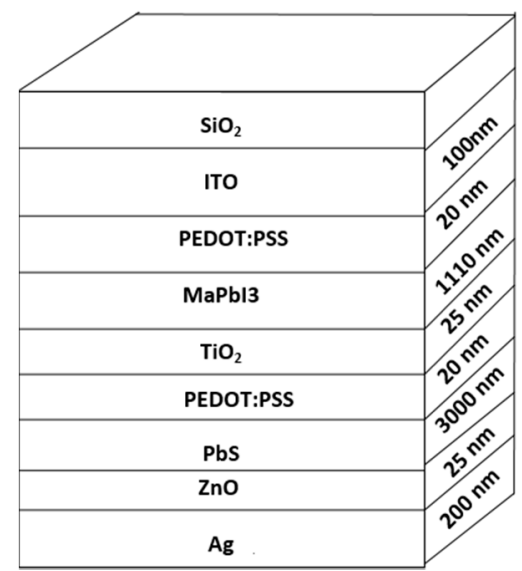

(a)

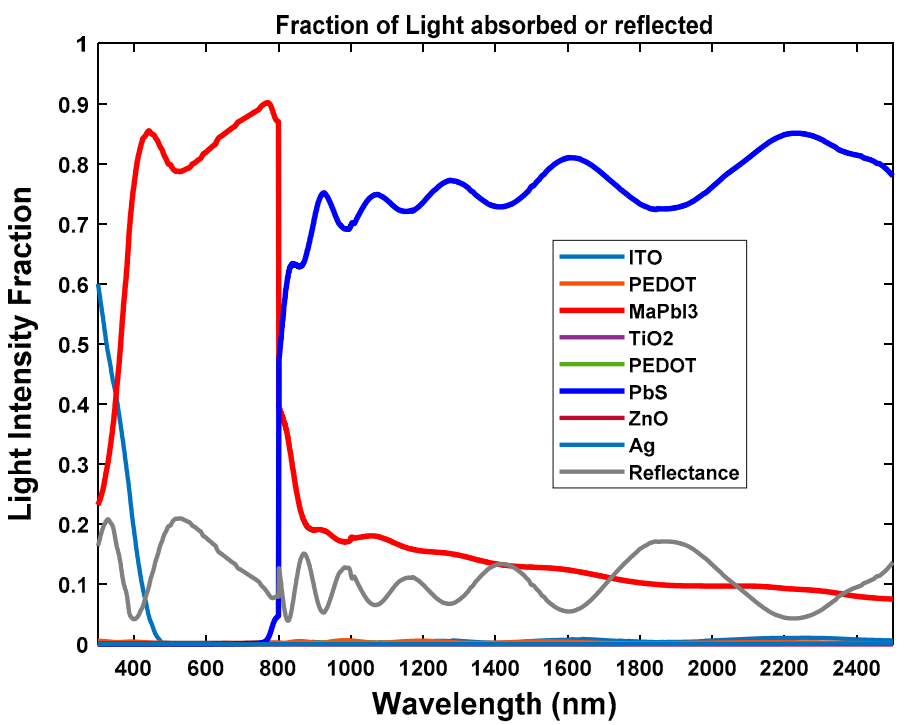

(b)

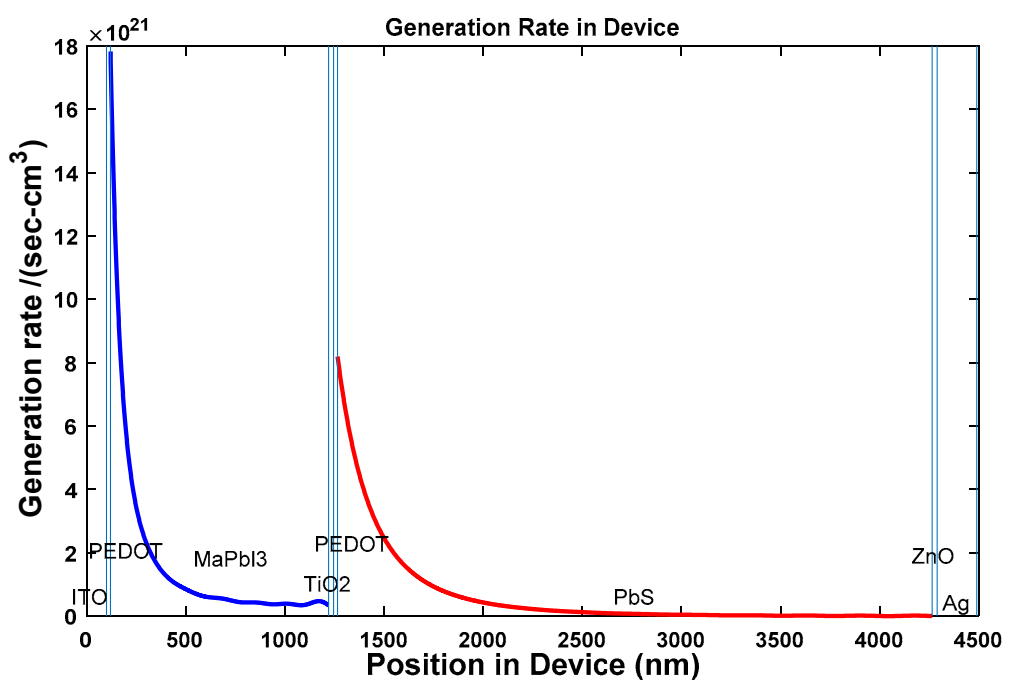

(c)

Figure 8. (a) Stack diagram; (b) variation of light intensity versus wavelength for $\mathrm{HSC} \mathrm{MaPbI}_{3}$ and rear $\mathrm{PbS}$ active layers; and (c) exciton generation rate vs. position of device for two-junction hybrid solar cell.

\subsubsection{Three-Junction Hybrid Solar Cell}

The second solar cell investigated was the three-junction HSC. The active layer of P3HT: ICBA is organic but $\mathrm{MaPbI}_{3}$ is both inorganic and organic and $\mathrm{PbS}$ is inorganic in nature. During the first step, we determined the optical properties of a cell whose dimensions are given by: Glass/ITO (100 nm)/PEDOT:PSS (30 nm)/P3HT:ICBA (2000 nm)/ $\mathrm{TiO}_{2}(15 \mathrm{~nm}) / \mathrm{NiO}(20 \mathrm{~nm}) / \mathrm{MAPbI}_{3}$ $(1700 \mathrm{~nm}) / \mathrm{TiO}_{2}(15 \mathrm{~nm}) / \mathrm{NiO}(20 \mathrm{~nm}) / \mathrm{PbS}(1000 \mathrm{~nm}) / \mathrm{ZnO}(15 \mathrm{~nm}) / \mathrm{Ag}(200 \mathrm{~nm})$. The stack diagram for the three-junction OSC is shown in Figure 9a. From Figure 9b, we can see that the three active layers of P3HT: ICBA, $\mathrm{MaPbI}_{3}$ and rear $\mathrm{PbS}$ active layers cover the solar spectrum with wavelengths of $300-2500 \mathrm{~nm}$ and the light intensity is above $80 \%$. From Figure 9c, we can see that the three active layers are producing excitons. 


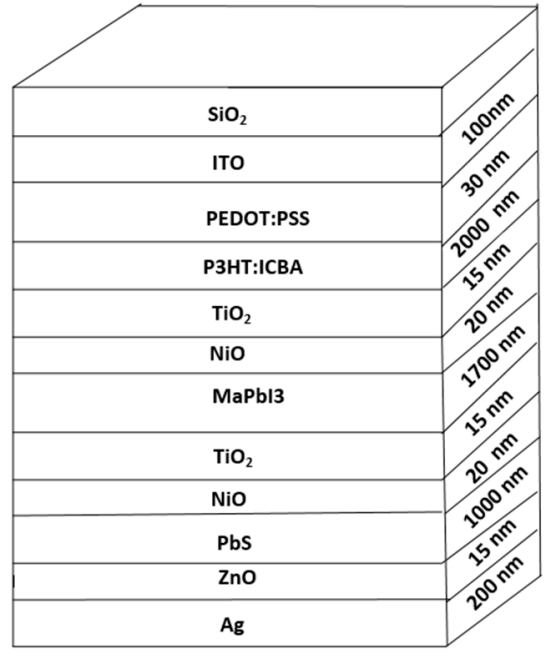

(a)

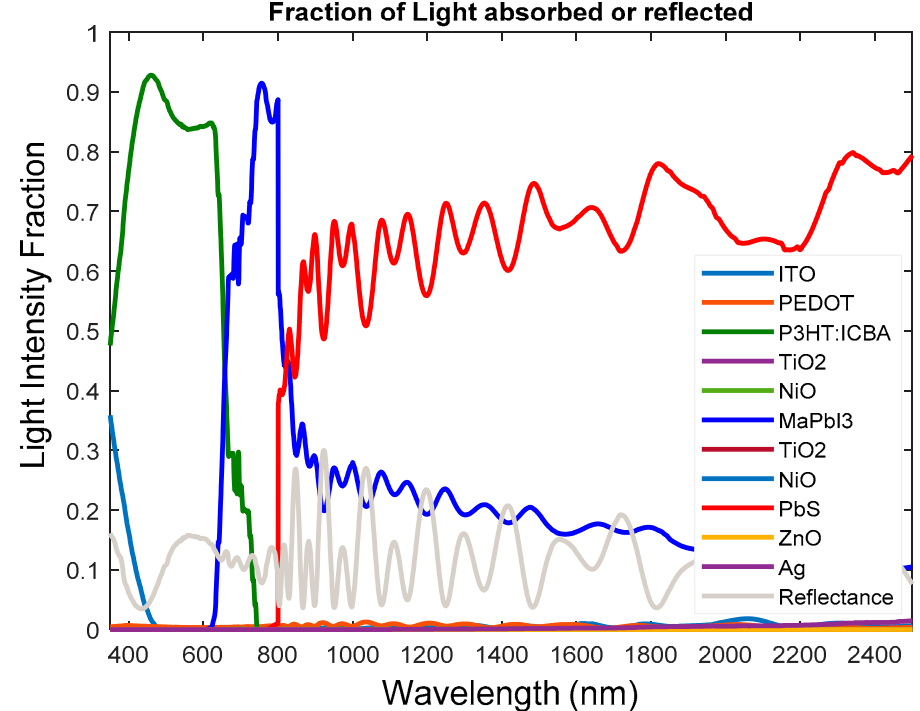

(b)

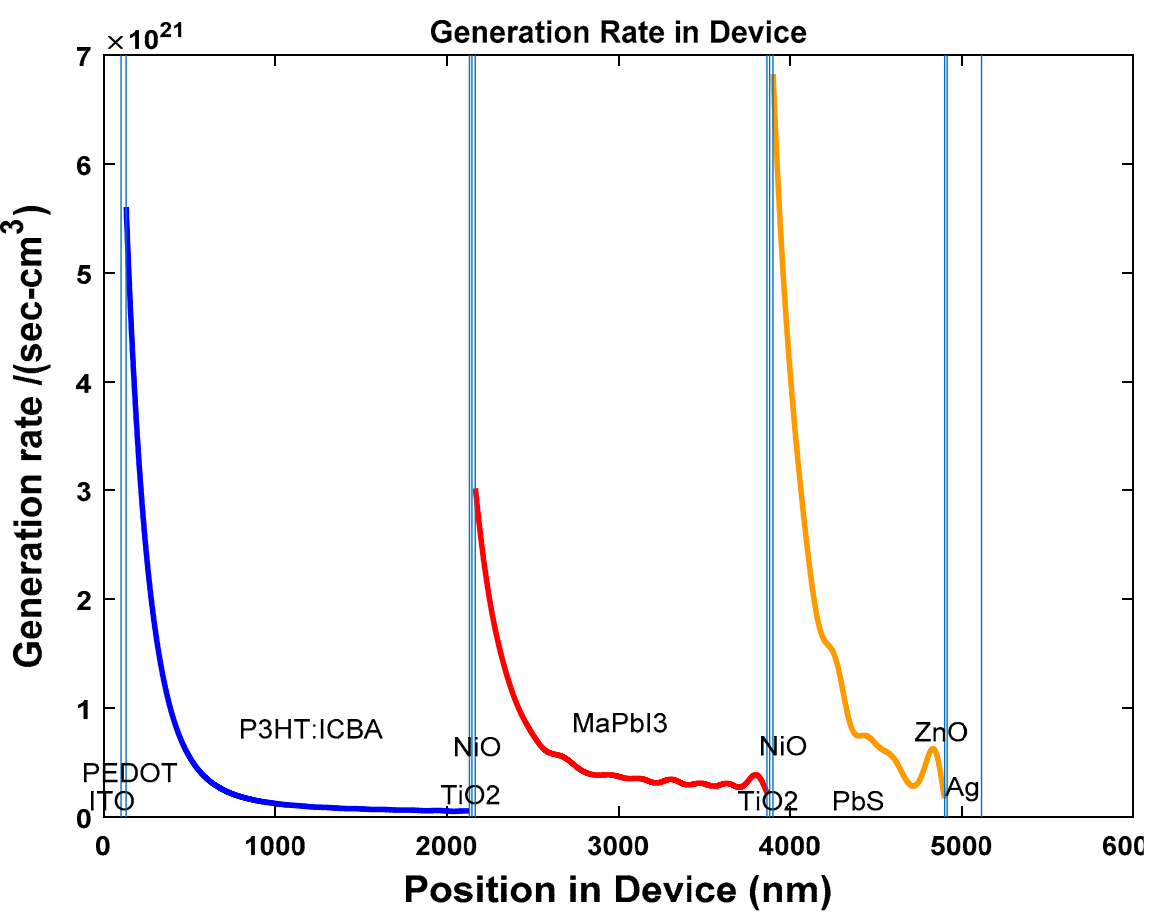

(c)

Figure 9. (a) Stack diagram; (b) variation of light intensity versus wavelength; and (c) exciton generation rate vs. position of device for three-junction hybrid solar cell.

\subsubsection{Four-Junction Hybrid Solar Cell}

The third solar cell that was investigated was the four-junction HSC. During the first step, we determined the optical properties of a cell whose dimensions are given by: Glass/ITO (100 nm)/PEDOT:PSS (20 nm)/P3HT:ICBA $(500 \mathrm{~nm}) / \mathrm{TiO}_{2}(15 \mathrm{~nm}) / \mathrm{NiO}(20 \mathrm{~nm}) / \mathrm{PTB} 7-\mathrm{Th}: \mathrm{PCBM}$ $(2000 \mathrm{~nm}) / \mathrm{TiO}_{2}(20 \mathrm{~nm}) / \mathrm{NiO}(15 \mathrm{~nm}) / \mathrm{PMDPP} 3 \mathrm{~T}: \mathrm{PCBM}(1100 \mathrm{~nm}) / \mathrm{TiO}_{2}(20 \mathrm{~nm}) / \mathrm{NiO}(15 \mathrm{~nm}) / \mathrm{PbS}$ $(1000 \mathrm{~nm}) / \mathrm{ZnO}(20 \mathrm{~nm}) / \mathrm{Ag}(200 \mathrm{~nm})$. The stack diagram for the three-junction OSC is shown in Figure 10a. From Figure 10b, we can see that the three active layers of P3HT: ICBA, PTB7-Th: PCBM, PMDPP3T: PCBM and PbS cover the solar spectrum with wavelengths of 300-2500 nm and the light intensity is above $80 \%$. From Figure 10c, we can see that the four active layers are producing excitons. 


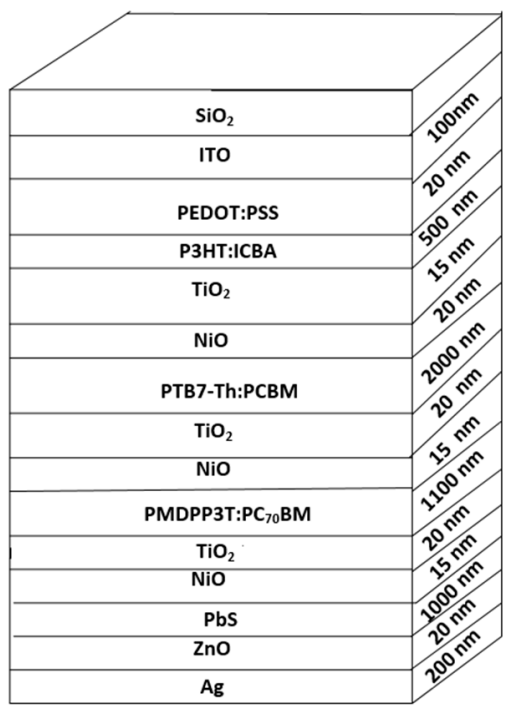

(a)

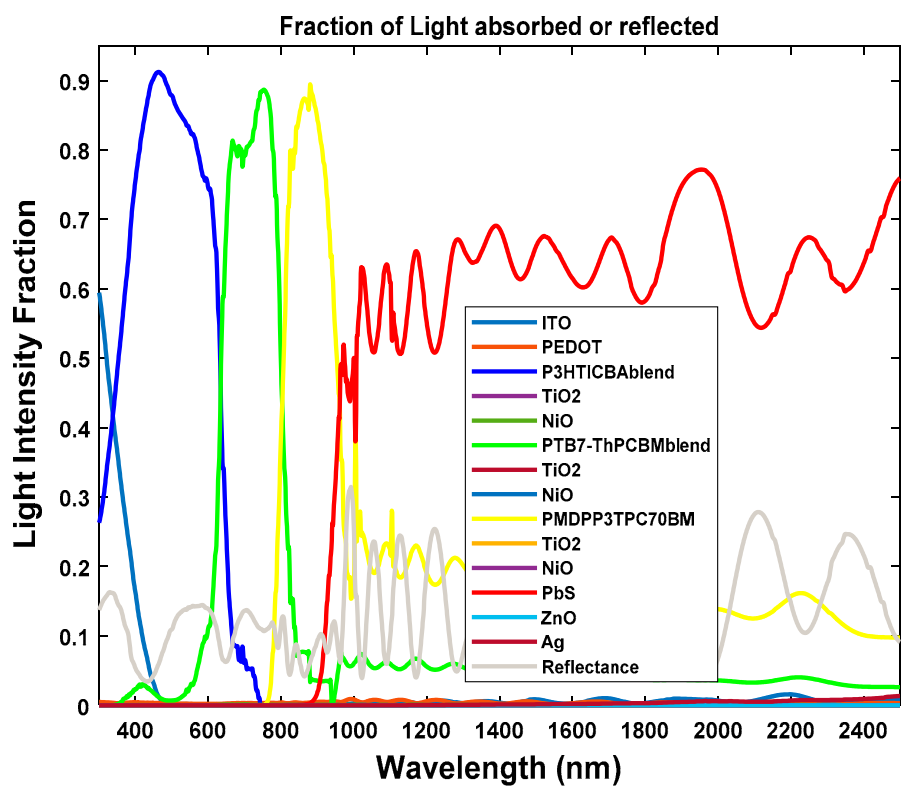

(b)

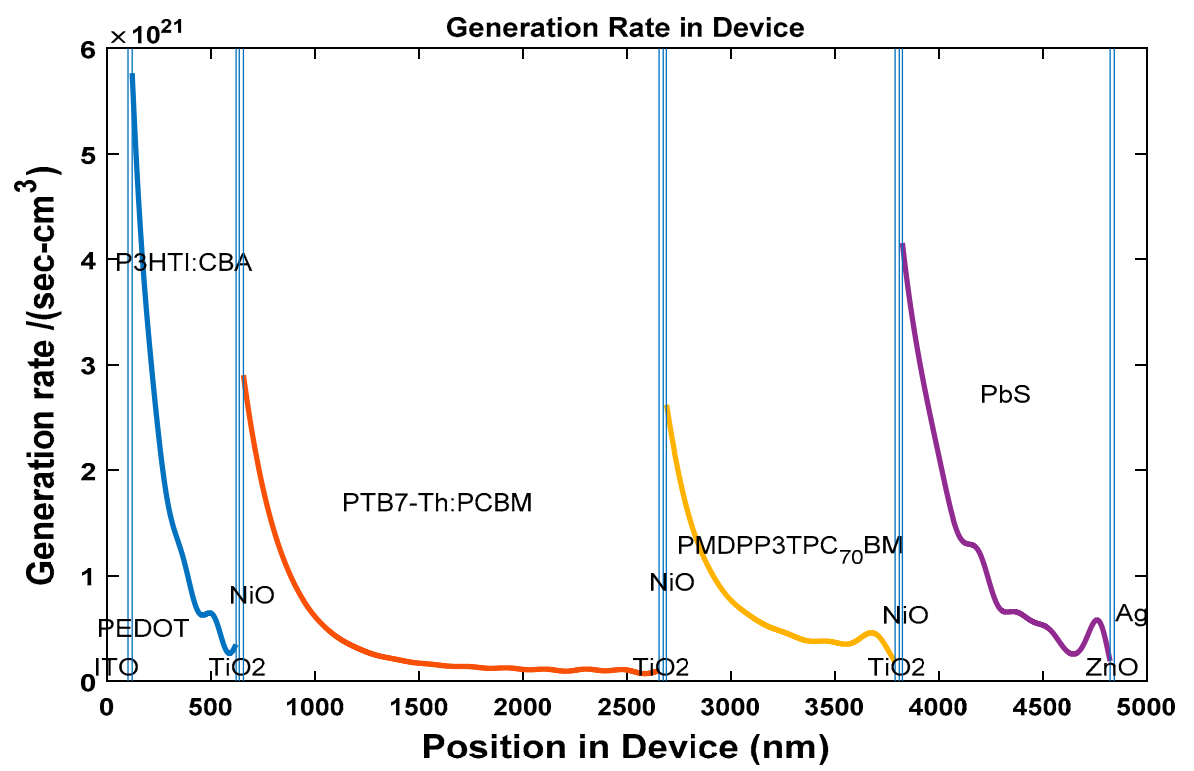

(c)

Figure 10. (a) Stack diagram; (b) variation of light intensity versus wavelength; and (c) exciton generation rate vs. position in device for two-junction hybrid solar cell.

\section{Discussions}

\subsection{Result Analysis for Three Types of Multi-Junction PSC and HSC}

For the three types of multi-junction polymer solar cells, the efficiency compared to fill factor graphs are shown in Figure 11. In Figure 11, we observed that the efficiency for all three types of PSCs are above 10\%. However, the P3HT:ICBA, PTB7-Th:PCBM and PDTP-DFBT:PCBM three-junction PSC has $12 \%$ efficiency. The J-V characteristics for two-, three- and four-junction hybrid solar cells are shown in Figure 12a, where we observed that two junctions produce a high $\mathrm{J}_{\mathrm{sc}}$ of $30 \mathrm{~mA} / \mathrm{cm}^{2}$ and four junctions produce a high $\mathrm{V}_{\text {oc }}$ of $2.8 \mathrm{~V}$. In Figure $12 \mathrm{~b}$, we also observed that the power conversion efficiency is above $20 \%$ for the two-, three- and four-junction hybrid solar cells. In Figure $12 \mathrm{~b}$, we can see that $\mathrm{MAPbI}_{3}$ and $\mathrm{PbS}$ two-junction hybrid solar cell provides $22 \%$ efficiency with a $55 \%$ fill factor. 
As the fill factor was close to $50 \%$ for all cells, this proves that there was reasonable series resistance (Rs) and parallel resistance $\left(\mathrm{R}_{\mathrm{sh}}\right)$ during the calculation of current density.

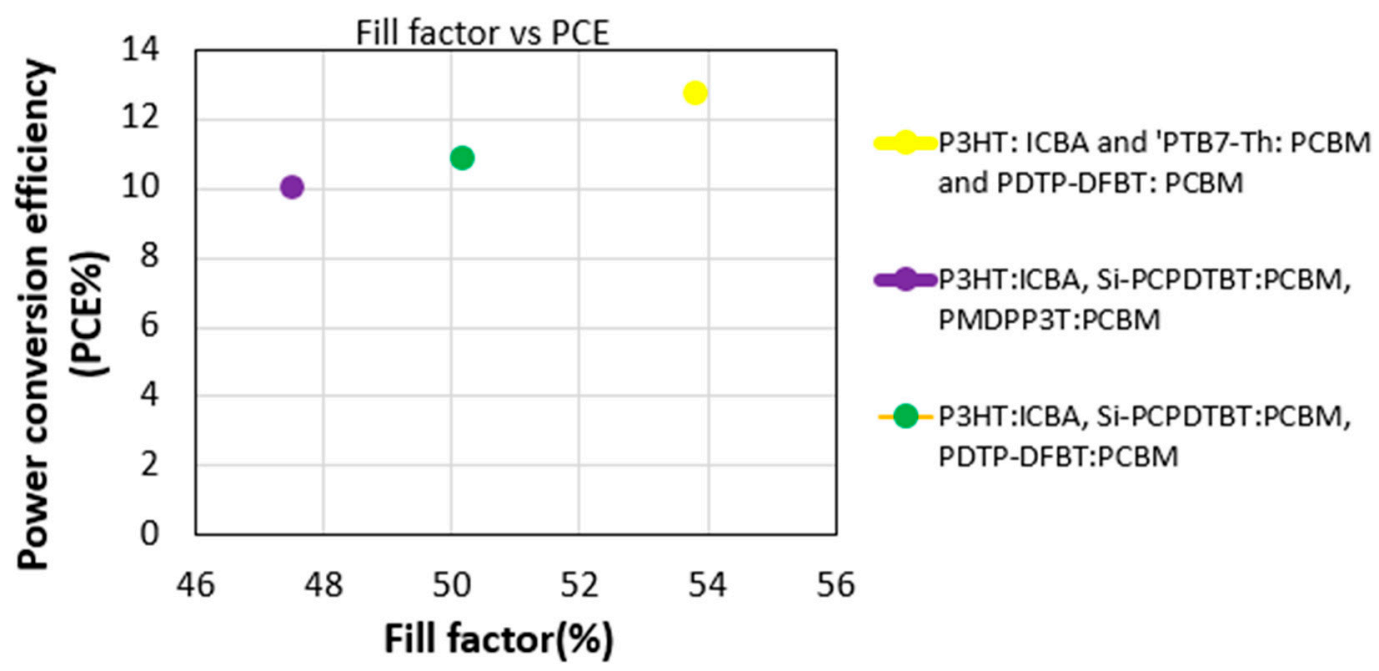

Figure 11. Efficiency vs. fill factor for multi-junction PSC.

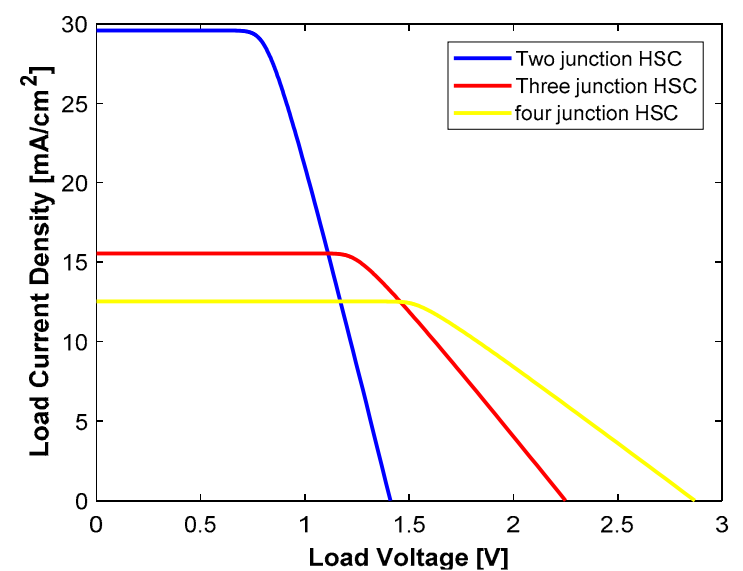

(a)

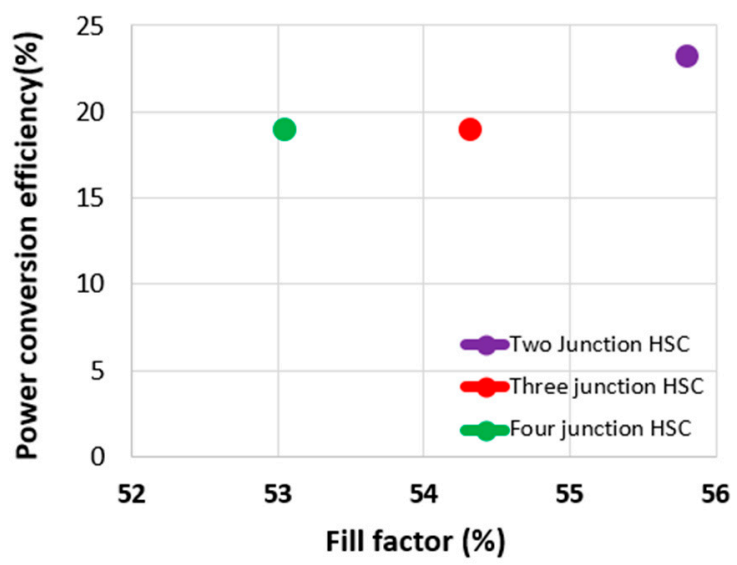

(b)

Figure 12. (a) J-V characteristics for two-, three- and four-junction hybrid solar cells. (b) Fill factor vs. efficiency for two-, three- and four-junction hybrid solar cells.

\subsection{Brief Fabrication Methodology for Multi-Junction Solar Cell}

Future works should focus on the fabrication of the multi-junction PSC and HSC. The solution-processed multi-junction solar cells can be fabricated as shown in Figure 13. First, the ITO-coated glass electrode needs to be cleaned and prepared. After that, the spin coating is performed for each layer of multi-junction PSC and HSC. After each spin coating, annealing is performed. Finally, the cathode electrode is deposited using thermal evaporation. 


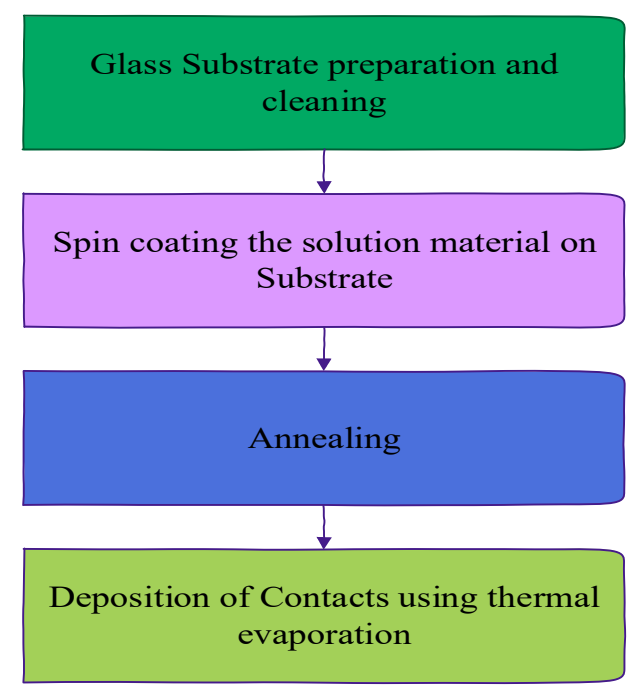

Figure 13. Fabrication methodology for multi-junction polymer and hybrid solar cell.

\subsection{Stability Analysis of PSC and HSC}

Organic solar cells degrade extremely fast. The efficiency of organic solar cell changes according to moisture levels. Maxim et al. reported that water is the key factor determining the degradation in a solar cell. Thus, there should be encapsulation of the cell so that the oxygen and moisture cannot come in contact directly with the materials of the solar cell. Future studies should determine the variation in the efficiency of the fabricated PSC and HSC with humidity [24].

\section{Conclusions}

Theoretical settings have been shown to improve the efficiency of the organic solar cells, which were determined by optical modeling using the transfer matrix. We showed how we optimized the various active layers for a type 1 multi-junction PSC. In multi-junction cells, the junctions are connected in series, hence each junction current should be equal. By varying the active layer, we found the optimum current for each junction. The open circuit voltage was calculated by the HOMO and LUMO levels of the materials, which were used as active layers in OSCs and HSCs. The simulations were performed using the Stanford model. The performance of the device varied with the active layer thickness. From the results of our simulations, we showed that our multi-junction polymer solar cell and hybrid polymer solar cell can provide high efficiencies. The maximum PCE of $12.73 \%$ was achieved from the multi-junction polymer solar cell with the three active layers of P3HT: ICBA, Si-PCPDTBT:PCBM and PMDPP3T:PCBM. Lead sulfide (PbS) was shown to be the most promising low bandgap inorganic material, as it can absorb sunlight beyond the infrared spectrum. By using inorganic $\mathrm{PbS}$ and high band organic materials, we created a solar cell that absorbs sunlight beyond wavelengths of $2500 \mathrm{~nm}$. The two-, three- and four-junction hybrid solar cells provided a PCE above $20 \%$. The two-junction hybrid solar cell provided a high current of $30 \mathrm{~mA} / \mathrm{cm}^{2}$ and the four-junction hybrid solar cell provided a high voltage of $2.8 \mathrm{~V}$.

\section{Patents}

A patent has been filed with Florida State University and it is pending.

Supplementary Materials: The following are available online at http:/ / www.mdpi.com/2073-4360/11/2/383/s1, Figure S1: Refrative index (n,k) vs wavelngth for PbS, Figure S2: Refrative index (n,k) vs wavelngth for $\mathrm{MAPbI}_{3}$, Figure S3: Refrative index (n,k) vs wavelngth for P3HT:ICBA blend, Figure S4: Refractive index (n,k) vs wavelngth for PMDPP3T:PCBM blend, Figure S5: Refractive index $(\mathrm{n}, \mathrm{k})$ vs wavelength for PTB 7 : PCBM blend, Figure S6: Refrative index $(n, k)$ vs wavelngth for PDTPDFBT: PCBM blend, Figure S7: Refractive index (n,k) vs wavelength for Si-PCPDTBT: PCBM blend, Figure S8: Refractive index $(n, k)$ vs wavelength for PCDTBT: PCBM blend. 
Author Contributions: For research Methodology, J.J.K.; Resources, S.Y.F.; Software, J.J.K.; Supervision, S.Y.F.; Validation, J.J.K. and S.Y.F.; Writing—original draft, J.J.K.; Writing—review \& editing, S.Y.F.

Funding: This work is funded in part by Florida A\&M University and Florida State University.

Conflicts of Interest: The authors declare that there is no conflict of interest.

\section{References}

1. Brabec, C.; Scherf, U.; Dyakonov, Y. Organic Photovoltaics: Materials, Device Physics and Manufacturing Technologies, 2nd ed.; Wiley-VCH: Hoboken, NJ, USA, 2014.

2. Luque, A.; Hegedus, S. Handbook of Photovoltaic Science and Engineering; Wiley: Hoboken, NJ, USA, 2003.

3. Shah, A. Thin-film Silicon Solar Cells; EPFL Press: Lausanne, Switzerland, 2010.

4. Choy, W.C.H.; Member, S.; Ren, X. Plasmon-Electrical Effects on Organic Solar Cells by Incorporation of Metal Nanostructures. IEEE J. Sel. Top. Quantum Electron. 2016, 22, 1-9. [CrossRef]

5. Raffaelle, R.P.; Anctil, A.; DiLeo, R.; Merrill, A.; Petrichenko, O.; Landi, B.J. Dye-sensitized bulk heterojunction polymer solar cells. In Proceedings of the 3rd IEEE Photovoltaic Specialists Conference, San Diego, CA, USA, 11-16 May 2008; pp. 3-8.

6. Wang, K.; Liu, C.; Meng, T.; Yi, C.; Gong, X. Inverted Organic Photovoltaic Cells. Chem. Soc. Rev. 2016, 45, 2937-2975. [CrossRef]

7. Karim, N.; Mime, F.I.; Islam, M.R.; Mehedi, I.M. Performance analysis of P3HT: PCBM based organic solar cell. In Proceedings of the 2017 International Conference on Electrical, Computer and Communication Engineering (ECCE), Cox's Bazar, Bangladesh, 16-18 February 2017; pp. 826-830.

8. Benaissa, O.M.; Hadjeri, S.; Zidi, S.A.; Benaissa, O.M. Modeling and Simulation of Grid Connected PV Generation System Using Matlab/Simulink. Int. J. Power Electron. Drive Syst. 2017, 8, 392-401.

9. Islam, M.S. Analytical modeling of organic solar cells including monomolecular recombination and carrier generation calculated by optical transfer matrix method. Org. Electron. 2017, 41, 143-156. [CrossRef]

10. Swapna, P.; Rao, Y.S. Modeling and simulation of organic solar cell using transfer matrix method. In Proceedings of the International Mutli-Conference on Automation, Computing, Communication, Control and Compressed Sensing (iMac4s), Kottayam, India, 22-23 March 2013; pp. 196-199.

11. Wei, F.; Yao, L.; Lan, F.; Li, G.; Liu, L. Tandem polymer solar cells: Simulation and optimization through a multiscale scheme. Beilstein J. Nanotechnol. 2017, 8, 123-133. [CrossRef]

12. Gagliardi, A.; Wang, S.; Albes, T. Simulation of charge Carrier mobility unbalance in organic solar cells. Org. Electron. Phys. Mater. Appl. 2018, 59, 171-176. [CrossRef]

13. Sigma-Aldrich Corp, Chemical Product Data Base. Available online: http://www.sigmaaldrich.com/ catalog/product/aldrich (accessed on 20 February 2019).

14. Abada, Z. Optical optimization of organic solar cells based on P3HT: PCBM interpenetrating blend. In Proceedings of the 5th International Conference on Electrical Engineering-Boumerdes (ICEE-B), Boumerdes, Algeria, 29-31 October 2017; pp. 3-8.

15. Roman, L.S.; Inganas, O. Modeling photocurrent action spectra of photovoltaic devices based on organic thin films Modeling photocurrent action spectra of photovoltaic devices based on organic thin films. J. Appl. Phys. 1999, 86, 487-496.

16. Yeboah, D.; Singh, J. Study of the Contributions of Donor and Acceptor Photoexcitations to Open Circuit Voltage in Bulk Heterojunction Organic Solar Cells. Electronics 2017, 64, 75. [CrossRef]

17. El Alamy, A.; Amine, A.; Hamidi, M.; Bouachrine, M. Conjugated molecules consisting of thienylenevinylene-co-cyanophenylene as donor materials for bulk heterojunction solar cells. J. Mater. Environ. Sci. 2018, 9, 918-927.

18. Yoon, W.; Boercker, J.E.; Lumb, M.P.; Placencia, D.; Foos, E.E.; Tischler, J.G. Enhanced Open-Circuit Voltage of PbS Nanocrystal Quantum Dot Solar Cells. Sci. Rep. 2013, 3, 2225. [CrossRef]

19. Pettersson, L.A.A.; Roman, L.S.; Inganas, O. Modeling photocurrent action spectra of photovoltaic devices based on organic thin films. J. Appl. Phys. 1999, 86, 487. [CrossRef]

20. Peumans, P.; Yakimov, A.; Forrest, S. Small molecular weight organic thin-film photodetectors and solar cells. J. Appl. Phys. 2003, 93, 3693. [CrossRef]

21. Burkhard, G.F.; Hoke, E.T. Transfer Matrix Optical Modeling. McGehee Group (Stanford Univ). 2011. Available online: http:/ / web.stanford.edu/group/mcgehee (accessed on 20 February 2019). 
22. Polyanskiy, M.N. Refractive Index Database. Available online: https:/ / refractiveindex.info (accessed on 20 February 2019).

23. Ioffe Physico-Technical Institute, $\mathrm{n}$ and k Data Base. Available online: http://www.ioffe.ru/SVA/NSM/nk/ (accessed on 20 February 2019).

24. Bora, B. Contemporary Research in Organic Solar Cell. Renew. Energy 2013, 6, 28-30. Available online: https:/ / mnre.gov.in/file-manager/akshay-urja/january-february-2013/EN/28-30.pdf (accessed on 20 February 2019).

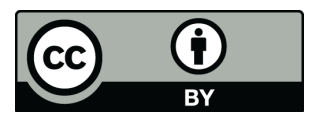

(C) 2019 by the authors. Licensee MDPI, Basel, Switzerland. This article is an open access article distributed under the terms and conditions of the Creative Commons Attribution (CC BY) license (http:/ / creativecommons.org/licenses/by/4.0/). 